\title{
Practical theology as life science: Fides Quaerens Vivendi and its connection to Hebrew thinking (Hālak)
}

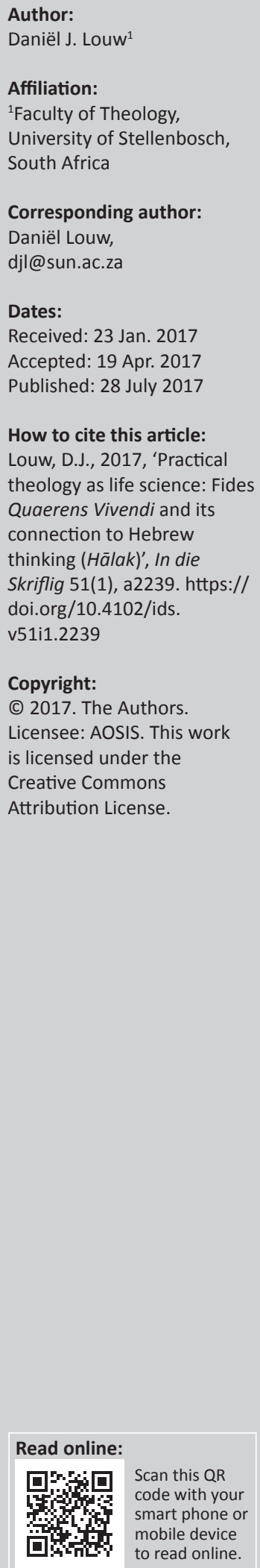

\begin{abstract}
The term practical theology is complex and, due to many different religious and cultural settings, a many layered concept. During the past 40 years the paradigm in theory formation for an academic and disciplinary approach to practical theology shifted from the clerical and ecclesial paradigm of ministerial actions to experiences of faith with the emphasis on an empirical based epistemology. Rather than a deductive approach, the shift is towards a more inductive approach within the methodological framework of phenomenology. Currently, in the international discourse on theory formation, there is a tendency towards a hermeneutical approach with the focus on the networking, relational dynamics of civil society Thus, the attempt to describe practical theology as a kind of 'life science' (the concern for the mundane and existential reality of everyday life-Alltagsreligion). Within the context of African spiritualties, with its emphasis on the communal dynamics of vital, human relationships, the focus on lifestyles becomes vital. In light of an ontology of life (l'energie spirituelle - Henri Bergson), the notion of fides quaerens vivendi [faith seeking lifestyles] is researched. With reference to the theory of complexification and chaosmos as well as the impact thereof on different theories in life sciences, the connection between sapientia and the vivid praxis of God is critically explored. The focus of this article is on the question: What is the impact of an ontology of life on both praxis thinking and theological reflection? Instead of the Cartesian framework of causative definitions, the notion of the 'infinition of God' is proposed within the praxis of Hebrew, wisdom thinking.
\end{abstract}

\section{Introduction}

Life is the most complex and mysterious issue and thus the reason why Henri Bergson (1946:7), in his philosophy of life, describes the praxis of life in terms of energetic spiritual entities (L'Energie Spirituelle). Life is about a process of becoming and imaginative creativity, a kind of soulful energy - an elan vital.

According to Bergson (1921:vii), spiritual energy is 'Mind-Energy', manifested in intuition. Praxis is a combination between spiritual energy and action. 'Activity seeking expression is the concept of Mind-Energy' (Bergson 1921:vii). The point in Bergson's argument (1946:14) is that life is composed by series of positions and thus the notion of transition and mobility in daily life experiences; the human being as a mobile of series of positions; '... let us restore to movement its mobility, to change its fluidity, to time its duration' (Bergson 1946:17).

As praxis principle, life is about a mindfulness and vital consciousness that points to a unifying, spiral dynamics and coherence factor: l'energie spirituelle. Practical reason (phronesis) or the praxis of thoughtfulness is not about a Cartesian a priori principle, ${ }^{1}$ but about a consciousness of life (elan vital) constantly penetrating the essence of daily life experiences by means of actions: '... thought is directed by action' (Bergson 1946:46). Praxis thinking is, in essence, about a kind of ontology of life - a life science.

The notion of 'life science' ${ }^{2}$ implies a shift from mechanistic causality (explanatory model) (Bergson 1944:43-57) to explosive evolvement (vital model). ${ }^{3}$ Life is an evolutionary process of 1. Radical instability and absolute immutability are therefore mere abstract views taken from outside of the continuity of real change, abstraction which the mind then hypostasizes into multiple states on the one hand, into thing or substance on the other' (Bergson 1946:184).

2.Life sciences comprise the fields of science that involve the scientific study of living organisms such as microorganisms, plants, animals, and human beings as well as related considerations like bioethics. While biology remains the centre piece of the life sciences, technological advances in molecular biology and biotechnology have led to a burgeoning of specialisations and interdisciplinary fields. Some life sciences focus on a specific type of life. For example, zoology is the study of animals, while botany is the study of plants. Other life sciences focus on aspects common to all or many life forms such as anatomy and genetics. Yet, other fields are interested in technological advances involving living things such as bio-engineering. Another major, though more specific, branch of life sciences, neuroscience, involves understanding the mind -. The life sciences are helpful in improving the quality and standard of life. They have applications in health, agriculture, medicine, and the pharmaceutical and food science industries. (Life science 2016).

3.'We do not think real time. But we live it, because life transcends intellect' (Bergson 1944:53); '... life is like a current passing from germ to germ through the medium of a developed organism' (p. 32). Existence is about a consciousness of tendency and intuitive activity of change - to exist is to change (Bergson 1944:10). 
becoming (Bergson 1944:179) due to the factor of indetermination inherently to matter (Bergson 1944:127-139). Even the human soul is a complex system of becoming and imaginative creativity -'soul' as a completing complex of becoming - Komplexerganzung (Selz in Driesch1925:68).

In medical terminology this 'complex of becoming', and vivid expansion of bio-psycho energy, has been described as a 'sense of aliveness' (Barton 1977:15-23) that emerges in a very significant way in dying patients and their struggle to hold onto life. The increasing confrontation with death and recognition of potential non-existence generate activity aimed at seeking personal significance - quest for significance and life.

With reference to the research of Barton one can hypothesise that the interplay between life, suffering, death and the human quest for meaning and care is the most fundamental 'praxis matter' in our human endeavour to cope with the demands of meaningful living. Thus, the following question arises: In what way can everyday life experiences, the happenstances of life, the urge to live meaningful, become object of research and reflection in practical theology?

According to Dille and Gärtner (2015:29), the notions life and praxis (the dynamics of everyday life-Alltagsreligion) should be fundamental in theory formation for practical theological reflection. The reflection of believers within daily life experiences and actions (Alltagsreligion), can be viewed as a specific methodology in doing theology, specifically within an academic environment, focussing on theological teaching and education (Dillen \& Gärtner 2015:69-70). At stake is how one lives one's faith (ordinary religion) within spiritual practices.

One general and overarching concept for practical theology is difficult, because it is used in different ways within different contexts (Dillen \& Gärtner 2015:86). Nevertheless, one can argue that life is a principle, a structural matter in the essence of being (Heidegger: Dasein). ${ }^{4}$ Thus, the question is whether practical theology implies more than merely actions, empirical reflection, the application of theological principles and propositions to practical matters. The argument is that there is a need in theory formation to attend to the concept of 'life science' (Seinsart von Lebenden) (Heidegger 1963:10) in practical theological reflection. How then is the concept of God related to the praxis structure of daily life forms and experiences (fides quaerens vivendi)?

\section{Theory formation in practical theology}

It was the practical theologian, Friedrich Schleiermacher, who brought about a radical change in the paradigms of theological and practical reflection and theory formation. He shifted the paradigms of practical theology from the hierarchical and clerical paradigm to the empirical dimension

4.The scientific study of being is about an ontology of the very structures of our being human in life (see Heidegger 1963:11). of human experience and religious experiences. Practical theology deals with 'applied' Christianity and is in this sense 'technical', that is, the development of skills and strategies for ministry (which he calls an art). Burkhart (1983:56) argues that, for Schleiermacher, practical theology is the art of overcoming the distance between human life and what it is meant to be.

Practical theology is often viewed as an action science (Handlungswissenchaft), trying to connect the Christian faith to the praxis and context of our modern or postmodern society (Heitink 1993:18). Communication and the empirical dimension of human actions and experiences have become focal areas in practical theological research (Van der Ven 1990:139). ${ }^{5}$ De Gruchy (2001:3-4) adds the dimension of transformation and the notion of aesthetic in human actions, that is, our ability to transcend the visible through imagination. Browning (1991:105) calls the aesthetic perspective the visional dimension of practical moral thinking. Cilliers (2012:67) connects the aesthetic dimension in practical theological thinking (fides quaerens imaginem) to the relational dynamics of life as expressed within social contexts and society and thus his reference to practical theology as fides quaerens societatum [faith seeking different modes of social embodiment].

Besides the performance-action paradigm (liberating practices of transformation), the connection practice-praxis includes the creative interplay between wisdom and imagination (fides quaerens imaginem). Practice and action are exponents of practical reasoning (phronesis) (Browning 1991). ${ }^{6}$ More than merely human activity is at stake in practical theological thinking. Praxis is about the undergirding theory in human actions; it refers to the significance and how of human orientation within the relational dynamics of everyday life. It includes an ontological as well as a teleological dimension. ${ }^{7}$ In Greek thinking praxis is fundamentally viewed as an expression of 'form' in order to connect 'essence', 'design' and function within concrete moments of observation and decision-making (Stace on Aristotle 1960:277).

But what about a hermeneutics of life and the existential realm of care (Sorge) $)^{8}$ and modes of being (habitus) (Dasein, Heidegger 1963)? Besides the paradigm of Greek thinking (analytical thinking), what about the paradigm of Hebrew thinking with the emphasis on life, wisdom and fellowship? In fact, praxis in Hebrew thinking is less analytical and more

5.Ruard Ganzevoort (2002:39) sees the human praxis of faith as the first order of reflection. 'It is the experiences and constructions of individuals and communities, responding to what they perceive, construct as coming from God, and their discourse about God and towards God.

6.Practical theology poses the question about the reason or intention of human actions as well as the norms and values that direct actions and influence decisions. Don Browning (1991:9-10) refers to this dimension of practical theology as the question about practical reason. In the context of the Christian faith it is the question about practical reason. In the context of the Christian faith it is the communities of faith.

7.'The word teleology means the view of things as adapting means towards purposive ends' (Stace 1960:101)

8.According to Heidegger (1963:324), care points to the human quest for meaning and purposefulness. It deals with the question: where to? 
synthetically; it is focused on wisdom within the realm of daily events.

In 2012 The Wiley-Blackwell companion to practical theology has been published. It is the conviction of Miller-McLemore and co-authors that there should be a paradigm shift from abstract issues to the happenstances of daily life events. The shift in practical theology should move away from religious meaning 'beyond the everyday' to religious meaning in the mundane (Miller-McLemore 2012:7). ${ }^{9}$ This shift is based on the assumption that everyday life constitutes a form of scientific pragmatism concerning our 'ordinary' empirical engagement with everyday objects (Baker 2007).

The shift to the mundane and everyday life experiences brings the interplay between praxis and concrete lifestyles (an ontology of life) or habitus into play.

Is it possible to reframe practical theology by means of an ontology of life? Practical theology is then interpreted as a life science: fides quaerens vivendi. Can a hermeneutics of faith in the tradition of Christian theology (fides quaerens intellectum) be translated into a hermeneutics of life with the focus on spiritual healing (wholeness) (cura vitae) (Louw 2008)? ${ }^{10}$

Furthermore, how can a philosophical understanding of life, within an interdisciplinary approach, assist theory formation in practical theological thinking and the attempt to connect praxis $^{11}$ to the existential dynamics of life?

Before we embark on the route to clarify the paradigmatic notion of fides quaerens vivendi, the question 'why?' should be posed. Why a paradigmatic shift from merely fides quaerens actum and fides quaerens intellctum, towards fides quaerens vivendi?

Iwant topoint outfive possiblereasons: first, interculturalisation and the quest for life and healing within African spiritualties; second, the complexity of life within 'practical realism'; third, the digitalisation of life and the impact of virtual reality and the social media on lifestyles; fourth, democratisation and global paranoia in civil society and the quest of refugees for home, space and place; and fifth, fortigenetics and the notion of psycho-social well-being in positive psychology with the focus on resilience in survival life strategies.

\section{Life within the framework of African spiritualities: interculturalisation}

When one takes the African environment seriously, life is viewed as an essential ingredient of our being human within the dynamics of human relationships (Kaunda 1967).

9.In short, in a variety of different settings in the past half century people have sought to reconfigure the relationship of theory and practice and to understand the value of practical knowledge and lived religion in ministerial study, in the study of religion and theology, and in the wider public' (Miller-McLemore 2012:4).

10.This question can be linked to the proposition of Don Browning (1983a:187): practical theological reflection, specifically in a pastoral hermeneutics, should be engaged in the challenge to articulate a normative and theoretical vision of the human life cycle.

11.As Tracy argues, 'the difference between practice and praxis is that in the latter the theory has been made self-conscious and reflected upon critically' (in Browning 1983b:13).
In Pastoral care to the sick in Africa, Berinyuu (1985:5) aptly points out that Africans are convinced that in the activities of life, harmony, balance or tranquillity must constantly be sought and maintained. For the African, life is a continuum of cosmic, social and personal events. It is not the individual who has to be cured; it is the broken ties and relationships that need to be healed.

African anthropology and spirituality is concerned with life as a whole:

It is not a pious behaviour but rather a commitment and involvement in a manner that gives meaning to life. Spirituality means that which influences a person to live in a mode that is truly fulfilling. (Skhakhane 1995:106)

What is envisaged in an African spirituality is harmony in interpersonal relationships: umuntu ungumuntu ngabantu/ motho ke motho ka batho [a person is a person through other people; author's free translation] (Mtetwa 1996:24). ${ }^{12}$ One is a human being through others (ubuntu principle)..$^{13}$ This notion of ubuntu is becoming a global concept in terms of the destiny of our being human.

To be human is to be connected to life. This is why Kahiga (2005:190) asserts that traditional African epistemology cannot be isolated from life events. ${ }^{14}$ The African paradigm is therefore about life and human events of interconnectedness and relatedness. Life never stands on its own but is embedded in the dialectics between life events and death. 'Life is a thesis and death is its antithesis. Life is to embrace and death is to depart and to isolate. The synthesis between life and death is becoming' (Kahiga 2005:190).

In African spirituality life is not as an abstract theoretical principle, but a networking dynamics embedded in cultural diversity and the everyday of human, relational dynamics.

Culture, ${ }^{15}$ from the Latin colo, means to nurse (take care of) or to transform the earth through a plough (an instrument) in order to live. Culture therefore refers to the human achievement and endeavour which tries to 'cultivate' creation and the cosmos into a humane space for living through symbols, metaphors, language and instruments (technical interventions).

In an intercultural hermeneutical model we no longer work with the split between Christ and culture (cf. Niebuhr 1952), but with the interconnectedness between Christ and culture.

12.'So, for example, the Zulu concepts imphilo and amandla describe the uniqueness of a person. 'In the combination of these two, life and life-force, imphilo and amandla, I daresay we find the combination which is the essence of man in Africa' (Berglund 1967:40)

13.'The spirit of Ubuntu - that profound African sense that we are human only through the humanity of other human beings - is not a parochial phenomenon, but has added globally to our common search for a better world' (Mandela 2005:82).

14.The present is the arena of life in its fullness and, as such, it is to be celebrated now. The fullness of life lies on earth in the present (despite the threat of evil, disease, pain, chaos and death) (see Twesigye 1996:216).

15.For the background to the concept of culture, see Van Binsbergen (2003:465-469). He refers to Tylor's definition: 'that complex whole which includes knowledge, belief, art, morals, law, custom and any other capabilities and habits acquired by man as a member of society'. In this regard, Van Binsbergen (2003:476) prefers the concept cultural orientation rather than merely culture. 
Interculturality ${ }^{16}$ is about the meaning of Christian spirituality within culture as well as the mutual influence and exchange of paradigms between the two. Although one cannot ignore the tendencies of repudiation (anti-), assimilation, accommodation, paradox and transformation, the tension between exclusiveness and inclusiveness, between continuity and discontinuity (which will always exist and cannot be resolved by rational categories), interculturality describes mutuality in terms of a hermeneutical process of understanding or interpretation, enrichment and critical exchange without the sacrifice of uniqueness. This is what Villa-Vicencio (1994:122-124) calls the 'encounter of the ultimate within and through the particular'. The particular in African spiritualties is embedded in the complexities of human relationships and the dynamics of vivid life events.

\section{Towards an ontology of everyday life: practical realism within the framework of chaosmos and complex networking}

With reference to Henri Bergson' philosophy of life, one can say that everyday objects possess inherently a kind of ontological significance that contributes to a practical realism. It leads to the notion of a metaphysics of everyday life (Baker 2007), that is, the assumption that everyday objects contribute to the experience: life is 'real' and carry a meaning that should be deciphered by a kind of common, practical knowledge (wisdom). Ordinary objects shape attitudes, practices and the significance of life experiences.

Rather than the option of a postmodern amorality, the emphasis in an ontology of everyday life should be existential responsibility (respondeo ergo sum): insightful responsiveness (Deetz 1992:3). An everyday ontology of life is about Gadamer's ontology of understanding and Faucoult's discursive structures (in Deetz 1992:9).

Snedeker (1984:277-291) refers to Jean-Paul Sartre and his analyses of the structures of capitalist society. He tried to explain human social practices in terms of ontological conceptions of human nature. Everyday life includes acts, passions, work, human needs as well as economic categories. Human beings should be defined in terms of the relation of becoming and the struggle to face the fact of negation in the event of decisionmaking; nothingness lurks in the very essence of being (Sartre 1943: L'Être et le Néante). Sartre posits human freedom as the need to go beyond the historical facticity of reified institutions and social relations. In this context, need is understood as lack, and freedom (in the form of praxis) attempts to surpass this condition of negation (Snedeker 1984:278).

In this formulation of the problem, everyday life is presented as contradiction and struggle within the dynamics of change and movement.

When one links life to pragmatic and practical issues, the 'creative mind' explodes energy that shapes a new form and

16.Villa-Vicencio (1994:120) connects interculturality to the necessity of an interreligious dialogue. With the forging of a common sense of belonging, South Africa is in need of a cultural openness, which involves a co-mingling of cultures, with a presumption of equal worth. mode of pragmatism. With reference to William James, Bergson (1946) aptly remarks:

The true, according to William James, does not copy something which has been or which is: it announces what will be, or rather it prepares our action upon what is going to be. Philosophy has a natural tendency to have truth look backward: for James it looks ahead. (p. 255)

Reality is thus redundant and superabundant (Bergson 1946:249) due to a force that operates like a 'vital principle' that is capable of battling against the physical forces and thwarting their action (p. 242) - one can therefore call soul 'a certain preoccupation with life' (p. 229). Thus, the principle of elan vital: 'Everything comes to life around us, everything is revivified in us' (Bergson 1946:186).

As Steven White (in Coole \& Frost 2010:5) pointed out: ontology not simply involves the abstract study of the nature of being, but also the underlying beliefs about existence that shape our everyday relationships to ourselves, to others and to the cosmic world. 'Ontological commitments in this sense are thus entangled with questions of identity and history, with how we articulate the meaning of our lives, both individually and collectively' (White in Coole \& Frost 2010:5).

In the summoning of a 'new materialism' (Coole \& Frost 2010:5-6), the assumption is that social constructivism is not enough to understand and reshape meaningful life orientation. Neither empiricism, nor positivism, but a 'theoretical rapprochement with materialism' (Coole \& Frost 2010:6) is most needed for meaningful orientation in everyday living. Active materialisation ${ }^{17}$ incorporates embodied human beings as integral components of daily changes. Materiality is always something more than mere 'matter', but active vital dynamic processes of unpredictable productivity and energy.

Instead of a linear logic of cause and effect, and the image of a solid world with bounded objects in space and place that moves according to controllability, predictability and replicability, an ontology of life is about theories that surpasses exploitation and manipulation of life as a means for greedy survival of the human species.

The interplay between habitus (respondeo ergo sum) and life virtues presupposes common knowledge (wisdom) and is thus the emphasis on a hermeneutics of life from the spiritual perspective of signifying and denoting meaning in life, a 'nonreflexive habituality of creativity and common-sense' (wisdom) (Coole \& Frost 2010:34). Life trajectories are exposed to unpredictable surprises that challenge wisdom thinking (sapientia of habitus); ${ }^{18}$ life as a void space of unpredictable dynamic events that surpasses positivistic predestinations and causative teleology.

17.For Bergson (1946:137) ideas are not nominal abstractions, but vital extractions and thus, embedded in the vitality of matter itself. (". general abstract ideas, abstracted, that is, extracted from matter'). Ideas are not $a$ priori - it is concepts abstracted, that is, extracted from matter').
already fixed in language (Bergson 1946:53).

18.'Practice meant that aspect of the habitus, or wisdom, in which the divine object sets requirements of obedience and life. Both reside in the single existential habitus called theology. Theory/practice is based here on what could be called a phenomenology of theology as habitus' (Farley 1983:27). 
Life oscillates between order and disorder. Life is about a chaosmos [dark matter] of complexifications (complexity theory), rather than a logical order of positivistic complifications (Morin 1992; 2008). Chaos is a science of process, rather than state; of becoming rather than being. It is about nonlinear provenance and emergent systems of at randomness (Coole \& Frost 2010:13-14).

Life is not stable, but exposed to change; it has to reckon with unexpected interruptions and trauma. Continuity also implies discontinuity. Even culture is not a static phenomenon and exposed to disorder. The philosopher Nassim Taleb (2012:4) calls this acute awareness of the unexpected, antifragility. ${ }^{19}$ Taleb (2010:xxix) concurs that almost 'everything in social life is produced by rare but consequential shocks and jumps ...'. Life is embedded and framed by paradox and complexity. One has to reckon with the notion of hyper-complexity (Morin 2008:21).

In complexity thinking, paradoxes are rendered as intrinsic components of reality. According to Stacey (in Nilson 2007:239), paradox implies an apparent contradiction, a state in which two apparently conflicting elements appear to be operating at the same time. One is then aware of the fact that contradictory, essentially conflicting ideas cannot necessarily be eliminated or resolved. Complexity thinking thus differs from rationalistic thinking in the sense that components are not organised in a homogenous way, but are embedded in the interplay between order and disorder (theory of chaosmos). 'Ontologically, the underlying belief is that of unorder and subjectivity; epistemologically, of heuristics or antipositivism; and teleologically, of a transformative nature' (Nilson 2007:239). As argued by Henri Bergson (1944:253): 'That order exists is a fact. But, on the other hand, disorder, which appears to us to be less than order, is, it seems, of right.'

Life events are then about considerable complexity, instability and volatility. The distinction between life and death has become a complex system of uncalculated and undefinable quality. 'Thing' or substance is about complex 'infinitives' rather than in logical 'definitives'. Even epistemology is about amazing evolving systems and new unexpected forms of networking. Life is not about quantitative relationships of cause and effect, but about qualitative relationships of synthetic wholeness (synthetic life forma and values).

\section{Life within the parameters of an entertainment and digital society: virtual reality and spirituality on line}

Deetz (1992) argues that the corporate organisation has become the most central institution in modern society. Everything, from personal identity and use of natural resources to definition of values and distribution of goods in society and services, has increasingly become under corporate control. The extent of the modern corporate encroachment into non-work and noneconomic sectors of life and its domination of other

19.The antifragile loves randomness and uncertainty, which also means - crucially-a love for errors, a certain class of errors. Antifragility has a singular property of allowing us to deal with the unknown, to do things without understanding them and do them well' (Taleb 2012:4). institutions, might, according to Deetz (1992), be properly called a new colonising activity - a colonising of public decision-making, and of the significance and value of the everyday life world. Big companies, director boards and commercial organisations make decisions for the public, but rarely are these decisions grounded in democratic processes.

It is the conviction of Roger Silverstone (1994) that information technology is shaping a new kind of ontology, namely a place called virtually home, that is, a togetherness and entertainment that focuses on home as a place of reorientation around the artificiality of data that influences everyday life. Television creates 'essential social tensions' between individual psychology, domestic and suburban spaces, and industrial and technological structures (Silverstone 1994:x-xi). An ontology of television homes in on the quest for order and preserving continuity within chaos and discontinuity. In this sense, television is creating an illusion of the distanced world that is otherwise entirely out of reach. Virtual reality, thus, represents everyday life and becomes part of the daily fabric of ordinary experiences: an ontology of the cosmos at home (Silverstone 1994:2).

Human beings tend to take everyday life for granted. In an ontology of everyday life, television also became a for granted device that accompanies us as we wake up, as we breakfast and as we drink in bars. 'It comforts us when we are alone. It helps us sleep. It gives us pleasure, it bores us and sometimes it challenges us. It provides us with opportunities to be both sociable and solitary' (Silverstone 1994:3). According to McLuhan (in Han 2013:20), the homo electronicus [man as an electronic devise] is a virtual manifestation of the previous century's achievement ethics with its emphasis on homo faber [man as the maker of things].

Due to technology and the introduction of the Internet the options, opened by virtual reality, contributed to the fact that homo spectans [human beings as spectators and viewers of phenomena] became fascinated by cyber-spatial metaphysics; the pro-spection of the World Wide Web sets free the dynamics of hope online. This kind of online hope is closely connected to the information revolution of the High-Tec age, which is also called 'the answers age': 'The answers business is the future' (Grunwald 2014:35). From floppy disks, compact discs to flash drives and the cloud, we live in an age of Great Optimising.

Human beings become focused on the beyond of cyberspace, networking webpages, the liminality between the seen and the unseen, and the mysticism of interface. The facelessness of Facebook, Twitter, LinkedIn and WhatsApp become a secure hiding place for a meta-physics of psychic curiosity online. This world of homo digitalis shapes a digital profile with options for new kind of anonymity with the facelessness of 'smart mobs' (Han 2013:20) - the so-called empire of the multitude or an interconnectivity through and from singularity.

The meta-realm of cyberspace brought about a revolution in terms of the different dimensions of religious experiences. Karaflogka (2002:191) refers to cyberspace as a polymorphic conception. Beyond geographical terms, the meta of cyberspace 
cannot be demarcated. The reality of cyberspace is 'nowhere' and yet its presence is felt 'everywhere' (Benschop in Karaflogka 2002:192). It creates an 'utopia online'.

One can say that homo spectans has been transformed into a new citizen - the so-called 'netizen' (Karaflogka 2002:192).

Cyberspatial phenomena created a new mode of metaphysics. It combines religious thinking with hypertexts of virtual immortality and the 'cyber-community' behind the present reality, namely the reality online. Spirituality online is about a religious, spiritual and/or metaphysical expression, which is created and exists exclusively in cyberspace where it enjoys a notable degree of 'virtual reality'. 'The world inside the screen can become more real than the world outside' (Grunwald 2014:34). ${ }^{20}$

Within the framework of digitalisation, life has become a cyberspatial reality. Life is not merely a biological or physiological entity, but a spiritual realm that is creating the hyper-reality of a virtual online spirituality. Online spirituality shapes everyday life into a new kind of 'cyber human being'. Citizens are no more merely civil entities, but cyber entities.

\section{Democratisation and global paranoia in civil society: the danger of escapism (civil idiotism) and the life quest for home and space (sense of belongingness)}

Henri de Lubac (1965), a French Jesuit priest, and perhaps one of the most influential theologians of the 20th century, argued that Christian spirituality has to move from abstract speculation to creative thinking within the realm of contemporary society.

Nicolai Berdjajew (1874-1948) identified, in the cultural history of humankind, four periods: non-civilisation (barbarism); processes of culturalisation (human development); epochs of civilisation (value and normative development); reflection and religious transfiguration (spiritual development). However, civilisation and technology are forcing theological reflection to move from religious transfiguration to the pragmatics of social life issues and radical processes of transformation. The shift is from 'miracles' (instant spirituality) to 'civil engagement' (organic spirituality). Civilisation, technology and society should constitute the framework for theological reflection (Berdjajew 1965). On the agenda of practical theological reflection is the dynamics within local communities and grassroots issues within civil society.

Civil society ${ }^{21}$ is about a networking dynamics between community structures, governance of state, economic enterprises and judicial decision-making. Its focus is to describe the impact of social and economic policy on daily structures of life within local communities.

20.'The Internet in this case is used as an environment which supports and nurtures the "rise of a new conceptual framework and language for religious experience suited to the changed environmental conditions of postmodern society" (Karaflogka 2002:193-194).

21.'The civil society' does not exist as a kind of phenomenon. Seligman (1992:200 204), in his research on The idea of civil society, differentiate between three basic descriptive functions, namely political, socio-scientific and philosophicalprescriptive functions.
J. Keane (2003) refers to the fact that the construct civil society is not a static fait accompli:

It is an unfinished project that consists of sometimes thick, sometimes thinly stretched networks, pyramids and the huband-spoke clusters of socio-economic institutions and actors who organize themselves across borders, with the deliberate aim of drawing the world together in new ways. (p. 8)

Due to the influence of economic forces on social and cultural processes, the function of civil society is inter alia about the mobilisation of forces and social energy outside the sphere of organised political powers and the connection to state and governmental structures. It entails more than merely the mobilisation of the private sector, and reflects the values and norms in the global village and its impact on processes of glocalisation.

In order to give a more concrete approach to the notion of 'civil society' one can argue that it consists of five dynamic dimensions: first, civil society awareness/sensitivity; second, civil society engagements/activities; third, civil society organisations; fourth, civil society structures and the link to, fifthly, civil society economics. Together they create what can be called a 'civil society networking within processes of globalisation' and universal democratisation.

Civil society creates a public space for the doing of practical theology and the understanding of life as the arena for praxis thinking. The point is that, for the creation of a just society and the understanding of the role of the church in social issues, the flight into personal and individual escapism could be viewed as a kind of 'civil idiotism'.

Retreat into privacy went strongly against the grain of Greek thinking. 'An individual who retreated from politics and public life was called an idiotes - a person who lacks the knowledge and social skills that mature individuals can be expected to possess' (Plato 2015).

Plato's choice for the sustainability of a fair and just society as well as the fostering of sound principles for the implementation of democracy, is a paradigmatic turn towards the wisdom tradition of philosophy. ${ }^{22}$ To 'save' democracy from chaos, wisdom thinking is most needed.

At present life in the global ${ }^{23}$ village and processes of democratisation are threatened by what can be called the

22 in his Republic Plato (1946) warned as follows: the soul of the 'democratic type' is eventually possessed by

Insolence, Anarchy, Waste, and Impudence, those resplendent divinities crowned with garlands, whose praises they sing under flattering names: Insolence they call good breeding, Anarchy freedom, waste magnificence, and impudence a manly spirit. (p. 279)

Thus, Plato's conclusion (1946) regarding the habitus of 'democratic man':

His life is subject to no order or restraint, and has no wish to change an existence which he calls pleasant, free, and happy. That well describes the life of one whose motto is liberty and equality. (p. 280)

23.'Global village' is a phrase coined by Marshall McLuhan. In the early 1960s, McLuhan (2015) wrote that the visual, individualistic print culture would soon be

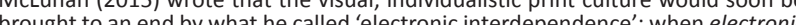
brought to an end by what he called 'electronic interdependence will move from individualism and fragmentation to a collective ide, humankind will move from individualism and fragmentation to a collective identity, with a 'tribal base.' McLuhan's coinage for this new social organization is the global village (McLuhan 2015). 
global paranoia of xenophobia due to the refugee and Syrian crisis (Walt 2015:8-9). Behzad Yaghmaian, a professor of political economy at Ramapo College of New Jersey, who wrote Embracing the Infidel: Stories of Muslim Migrants on the Journey West (in Vick 2015:31), remarks as follows: 'Because of globalisation, you have awareness of life elsewhere in the world. That's crucial now. So you move' (the dynamics of mobility: moving to a better world - pursuit of happiness, cult of prosperity and wealth).

According to Polak (2014:1), homo sapiens is in essence a homo migrans. Throughout history people were on the move. One can even say that migration is a social phenomenon and part of human existence (Castels \& Miller 2009:299). However, what is currently happening is that migration has become a feature of our being human in the so-called global village. Migration is about a new mode of defining identity, diversification within mass pluralisation. It is challenging our understanding of notions like national states, 'civil society', 'democracy' and 'human dignity'.

The discovery of a possible attack on vulnerable human beings (tourists) at Checkpoint Charlie in Berlin (February 2016) brings about a lot of negative reactions. According to Von Stephan-Andreas Casdorff (2016:1), these kinds of events are questioning the current 'Willkommenskultur' in Germany and fuel radical reactions and aggressive attitudes (Sorgen bereiten Aggressivität). According to Turkish President Tayyip Erdogan, 'We are confronted with collective terrorism activity around the world as terrorism does not recognise any religion, any race, any nation or any country' (Reuters 2015:11).

The dilemma is that citizens of the global village start to live in a kind of ambivalent situation, namely between resistance (anxiety and hate) and outreach, acceptance (mercy and trust). The dilemma of life in a global society is about the challenge of tolerance and accommodation within an atmosphere of suspicion and resistance. Eventually it boils over into the fear of the other (xenophobia). 'Right-wing parties that promote nativism and xenophobia were already on the rise in France, Greece and other E.U. nations well before the latest surge of migrants' (Vick 2015:32).

\section{Life: the quest for strength and resilience in psychosocial well-being (fortigenetics)}

With life science in psychology is meant to facilitate individuals in terms of their needs, framework of reference, conceptualisation of processes of epistemological knowing, discovering personal boundaries and limitations and planning in terms of preferred future orientation (Maree 2013:61).

With reference to a psychology of life, Rothman (2013:126) refers to the importance of flourishing ${ }^{24}$ in psychosocial wellbeing. It is about a pattern of positive feelings and positive

24.In positive psychology there is a debate on the interplay between happiness (pleasant life or positive emotions) and meaningful life (belonging to and serving in (pleasant life or positive emotions) and meaningful ife (belonging to and serving in (Antonov 1979:11). It is about hap) and engaged life (positive character) (Antonovsky 1979.11). It is about happiness orientation and meaning orientation: eudaimonia (Antonovsky 1979:11). The tendency is a shift away from individua happiness to a better life for all: human welfare. functioning in life, a sense of resiling. ${ }^{25}$ Positive psychology is about 'appraisals' individuals make regarding the quality of their lives, which does not only concern feeling good (e.g. satisfaction with life and a positive affect balance), but also functioning well - experiencing a kind of happiness and selffulfilment. It is about a satisfaction with life, being cheerful and in good spirit, and having a sense of accomplishment. It can also be connected to a sense of thriving (Rothman 2013: 128) - a psychological state in which individuals experience a sense of vitality and learning.

Positive psychology refers to the quest for harmony (balance, inner peace, self-acceptance and positive relationships) - a balanced life (Rothman 3012:134):

Positive psychology has expanded from a focus on subjective well-being, satisfaction with life, and hedonic happiness, to a focus on meaning and other facets as understood from an eudaimonic well-being perspective, as well as currently also attention to the integration of hedonic and eudaimonic facets. (Wissing 2013:1)

It is about the interplay between fortigenesis and salutogenesis in order to create a sense of resilience. ${ }^{26}$

'In the fortigenetic context, strength means being aware of a demand, a goal, and a direction in which to act. It also means having the inherent ability and energy to make the effort to do what is required' (Antonovsky 1979:9). It is linked to motivation, determination, steadfastness and endurance to continue acting.

In the debate on psychosocial well-being the notion of flourishing is preferred (Strümpfer 2013:15, 16) over against languishing at the bottom levels of a continuum of emotional, psychological and social well-being (emptiness, stagnation and quiet despair associated with impairment and burden in society) - experiencing incomplete mental health. Complete mental health points to a positive habitus of strength and courage (fortigenetics) in life.

\section{Praxis thinking: the networking dynamics of habit as exponent of qualitative life styles}

In light of the previous outline one can say the notion of lifestyle (vivendi) is currently demarcated by communality within

\footnotetext{
25.'The Latin roots of 'resile' are re-and salire, reflecting a process of jumping or bouncing back, or returning to the original condition' (Strümpfer 2013:17). It operates in risky or extraordinary contexts. Bouncing forward refers to constructive anticipation into the future (Strümpfer 2013:170) Strümpfer (2013) describes resilience

as a pattern of activity, starting with the appraisal of demands, which arouses a motive as a pattern of activity, starting with the appraisal of demands, which arouses a motive coping and rebounding, with accompanying emotions and cognitions. (p. 177)

26.Salutogenesis is the concept introduced by Antonovsky (1979) to describe the origins of health; the social physical and psychological dimensions. Salutogenesis describes 'a coping resource that is presumed to mitigate life stress by affecting the overall quality of one's cognitive and emotional appraisal of impacting stimuli (Antonovsky 1979:8). 'Fortigenesis is an expansion of salutogenesis; it is an attempt to more pointedly describe a condition of strength at multiple endpoints, more than just health alone. Fortology is the study of fortigenesis' (Antonovsky 1979:7). Fortigenesis is considered as being supported by resiling.

Resiling in turn may be strengthened by a range of char Resiling, in turn, may be strengthened by a range of characteristics and behaviors, for instance, agency, engagement, gratitude, hope, locus of control, maturity,
mindfulness, optimism, self-esteem, sense of humour, spirituality, wisdom, and more in addition to health-promoting activities. (Antonovsky 1979:7) more in addition to health-promoting activities. (Antonovsky 1979:7)
Important in this regard is a sense of coherence, general psychological well-being, self -efficacy and social support.
} 
cultural diversity (interculturalisation), complexity within a networking ontology of life' virtual reality and spirituality online, democratisation within the parameters of civil society and the global paranoia of xenophobia, and the human quest for courage and resilience within the acute awareness of human vulnerability and unexpected tragedy. These issues are ingredients of daily life experiences and challenges contemporary practical theological reflection. They have become core data for epistemology in methodology within the disciplinary field of practical theology. The spiral model in epistemology, theory-practice-theory (Van der Ven 1988:24) thus maintains that an empirical approach is important for valid scientific research in practical and pastoral theology (Heyns \& Pieterse 1990:47) with its focus on contextuality and the meaning of daily life events (Heitink 1993:19). Heitink, thus, describes practical theology as a communicative and action-oriented science. This approach implies that practical theology is empirical theology that mediates the Christian faith in the praxis of modern society (Heitink 1993:18).

Reader (2008:1) even goes so far to advocate for a revolution of categories in the field of theory formation in practical theology. He warns against the danger of 'zombie categories' (Ulrich Beck), that is, the continued employment of concepts that no longer do justice to the world we experience, and yet, difficult to abandon because of tradition and because they are not yet totally redundant. What has become important is the 'hermeneutical model of pastoral engagement' (Reader 2008:6) within life events.

Together with the search for categories to express the character of practical theology, the realm of existential issues and the link to the spiritual dimension of life is gaining field. With reference to the notion of 'reflexive spirituality', ${ }^{27}$ Reader (2008:73-80) probes for a self-awareness that is engaged in existential and life issues of a global society such as 'green spirituality' and the 'rise of the new economy' with its paradigmatic framework determined by knowledgebased information (the information technology revolution), global activities of production and consumption, and networking competition. (Reader 2008:103-104).

Within theology, 'reflexive spirituality' puts a huge challenge to an exclusive approach in ministry and ecclesiology. Rather than the traditional clerical paradigm, denominational demarcations and a selective morality, the focus on everyday life issues leads to what can be called an operative ecclesiology ${ }^{28}$ (Yves Congar in Bergson 2015) and a practical theology of habitus.

Already in 1983, Edward Farley (1983) advocated for the understanding of practice in Practical Theology as habitus. Theologia practica, for him (Farley 1983:27) is habitus: 'Practice

27.The value of Reader's attempt to reconstruct practical theology is that his 'reflective spirituality' puts anew on the agenda of practical theology the importance of philosophical schemata of interpretation that influence existing paradigms and patterns of thinking and critical reflection.

28.With operative ecclesiology is meant performative actions of being the church within concrete contexts. It reflects on ecclesial matters not merely from the within concrete contexts. Is rection viewpoint of denominational traditions and dog communal life systems. Ecclesiology may be studied inductively and can thus draw support from various other disciplines, such as political science, history and sociology (see Bergson 2015). meant that aspect of the habitus or wisdom in which the divine object sets requirements of obedience and life'. He points out that literature in the Middle Ages calls theology a 'habitus, a disposition, power, act of the soul itself'.

In essence knowledge is episteme, which points to habitus and to the quality of our being functions. In their book Siblings by choice, Smith and Riedel-Pfaefflin (2004:52) argue that habitus, in a systems approach, indicates a system of durable and transposable dispositions. Habitus serves as a culturally encoded way of being in the world that enables humans to co-operate and cope with the unforeseen and ever-changing situations of life. Habitus represents our position within historical and cultural settings and serves as an indication of the quality of our position in place and space (praxis of lifestyles) within the realm of daily life events.

\section{Life as focal point in practical theological reflection: towards a new paradigm in theory formation?}

In an introductory article on the edition of practical theology as a kind of life science, Martina Kumlehn (2011:4) argues that life should be taken up as a topic in scientific and academic reflection - specifically in theory formation for practical theology (Lebenswisssenschaft Praktische Theologie?!)

Already in 1975 Helmut Tacke defines the care of souls in terms of an involvement of our total being, with the Gospel acting as the mediating agent. This involvement occurs as an open dialogue which should represent the care of God. The purpose of the care of souls is therefore to offer faith care in such a way that the solution of existential problems should prove that faith care is, in fact, life care (Tacke 1975:32). Manfred Josuttis (1980:103) views the purpose of praxis engagements as life care. According to Josuttis, praxis thinking includes a social and welfare dimension. For this reason, caregiving, helping and healing must not be limited to the individual; otherwise it results in a kind of social blindness. In Josuttis's model for pastoral theology (1980), the basic thesis is that pastoral care is the praxis of the Gospel in the mode of liberation and social transformation. Ganzevoort (2002:34-42) advocated for a social construction in practical theological epistemology.

The emphasis on public issues in an operative ecclesiology $y^{29}$ implies a radical shift from the 'pomp and glory of the cathedral' to the 'public of the market place' - public settings as logus theologicus (Kessler 2014). The society, as a whole, should become the object of theological and practical reflection (Ferreira 2009:4). 'The process of conflict transformation and reconciliation is a matter not only for political experts or bureaucrats but for the society as a whole' (Leiner \& Palme 2014:10).

29. With operative ecclesiology is meant performative actions of being the church within concrete contexts. It reflects on ecclesial matters - not merely from the within communalife systemin. Ecclesiology support from various other disciplines, such as political science, history and sociology (see Bergson 2015). Practical theological reflection should start with the contexts, for example the current refugee crisis (Polak 2014:1-2). 
Public issues concerning the quality of life in civil society could be viewed as essential and core practical theological concerns. This emphasis can be linked with the very old wisdom tradition in Hebrew thinking.

Wisdom, (hokmah) refers not so much to God's acts of salvation in biblical history, but rather to daily human experience. The sayings in the Proverbs give an example of this experiential knowledge. 'The saying is a sentence usually expressed in the indicative mood and based upon experience' (Murphy 1990:7). Proverbs are expressed in instructions for everyday living. Scriptural wisdom should therefore not be interpreted dogmatically. Wisdom is more than just theory and rational knowledge. It also embraces practical life skills and is linked to human creativity, such as the works of art (cf. Ex 31:3-5; 36:1; Eynikel 1991:13). Wisdom is about public life le $^{30}$ issues: 'They deal with the concrete, how and when and why certain actions are to be performed and certain insights to be appropriated (cf. Pr 15:23; 25:11; Sir 4:23' (Murphy 1990:113). One can even argue that wisdom reflects something of the splendour and glory of God's presence in life. In this regard, Nell (2017:3) refers to the task of practical theology as the unfolding and performance of a kind of theo-drama.

According to Grethlein (2012:143-192), practical theology should be transformed as the theory of communicating the gospel in terms of existential life issues. In this regard, the concept life $^{31}$ is emerging more and more as focal point, overarching topic, and object in practical theological reflection and methodology. Martina Kumlehn (2011:4) argues for practical theology as a kind of life science. Together with religious experiences and spiritual awareness (transcendent experiences) ${ }^{32}$ (Lauster 2007:143), the interplay between life and meaning have become important ingredients of practical theological reflection on divine presence within the existential dynamics of daily life events. ${ }^{33}$

Communication implies, inter alia, helping people how to live and to cope with the demands of daily living (Helfen zum Leben) (Grethlein 2012:166); thus, the reason why human hopes features time and again as eventual framework for meaningful living. Hope represents the spiritual notion that life is about more than merely human achievements. Life includes the experience of 'the ultimate' - 'Jenseits' as a driving force in our 'Diesseits'. Life is the striving towards a

30. Most scholars nowadays agree that practical theology at its best functions 'as a kind of public theology sensitive to the individual but directed toward the wider kind of public theology sensitive to the individual but directed toward the wider sencal issues is a shift to normative construction (Osmer 2008:4) and practical engagement (action orientation).

31.In this regard, the link between the human spirit (Geist), and the quest for meaning and care (Sorge) become important topics in practical theological reflection (Lauster 2007:142-143)

32.The notion of transcendence points to the invisible realm of meaning, religious experiences and awareness of a kind of ultimate destiny that supersedes merely observational experiences. Due to internet and the media, transcendent experiences have become popularised (Die Transzendenzerfahrung wird popularisiert) (Grethlein 2012:177).

33.Former Archbishop Desmond Tutu (2004) put the following challenge on the table of communities of faith:

We were involved in the struggle because we believed we would evolve a new kind of society. A caring compassionate society. At the moment many, too many, of our people live in gruelling demeaning, dehumanising poverty. We are sitting on a powder keg. We really must work like mad to eradicate poverty. (p. 33 ) kind of fulfilment that connects sustainability with eternal images - (Mehrwert des Lebens) (Lauster 2007:146-147).

Kumlehn (2011:40 refers to practical theology as a science that should give attention to promoting a kind of 'religion of life' (Religion des Lebens). The presupposition is that there exists a close connection between life and religious experiences. Practical theology should thus be engaged in life issues; it should try to enhance the quality of life and focuses constantly on human well-being, health and healing (Heil). With reference to Pierre Bühler (in Kumlehn 2011:5), the challenge is how to understand life and create a hermeneutics of life in close connection (symbiosis) with the natural sciences, health sciences and technology.

Practical theology and caregiving are in essence engaged in life events with the view of healing and wholeness (cura animarum as cura vitae) (Louw 2008). Life, then, as a qualitative and relational category implies the systemic interplay between natural or cosmic forces, biological and physiological factors, structural and technological infrastructure. Life is an inclusive concept referring to existential challenges as embedded in the trajectories of daily life, spiritual matters as related to the ultimate realm of life as well as religious experiences. In this regard, life should be viewed as a networking category including the notion of transcendence and the human quest for meaning (significance) and dignity within the framework of values, belief systems, moral questions, convictions and philosophical constructions.

Life becomes thus a metaphor for a spirituality of significance and purposefulness (L'Energie Spirituelle, Bergson 1946:7). Thus, as Korsch (2011:342) ${ }^{34}$ argues, life should inevitably become an object of practical theological reflection and be linked to a metaphoric understanding (hermeneutics) of daily life events in order to open up new future options for human self-realisation.

What, then, is meant by a practical theology of lifestyles that can open up future options for meaningful human selfrealisation and the safeguarding of human dignity in the civil structures of everyday living?

\section{Towards a practical theology of lifestyles: praxis as 'way of life' (fides quaerens vivendi)}

In Jewish writings, the Hebrew hālak, corresponding with the Greek anastrephō, describes, in a figurative way, life as a 'way', a mode of walking in the way of God (positive) or walking in $\sin$ (negative). In a figurative sense, the verb anastrephō denotes the meaning of human behaviour: to walk, to conduct oneself, to live in a particular way (Ebel 1978a:933).

The way of life is about a designation for conduct of life. In this regard peripateo is used in a figurative sense as a description of a qualitative approach to life - an indication 34.The basic thesis of Korsch (2011:342) is that life is about self-fulfilment and selfrealisation (Leben ist Selbststeigerung). 
that one should conduct one's way of life in the paths of justice indicated by God's commandments. 'It obtains an outstanding significance as a term for denoting way of life; the nature and the manner of the way of life make it clear as to what governs a man in his being and acting' (Ebel 1978c:944).

In the New Testament anastrephō describes a way of life as new communion in Christ - to turn away from a previous way of life to a new life of obedience, piety and holiness (2 Cor 1:2; $1 \mathrm{Pt} 1: 15,17 ; 3: 16)$. Christian conduct is determined by fellowship with God and translates 'knowledge into practice' (Ebel 1978a:934). Fellowship with God implies a very specific praxis, namely to walk with God within the trajectories of life. Lifestyle denotes a kind of hodos (a kind of life). In a figurative sense, hodos as lifestyle describes the way one has to follow in order to reach a goal; '... hodos can acquire the meaning of the means and way of reaching or carrying out something, measures, procedure, the style and way in which one does something and in which one lives' (Ebel 1978b:935).

The Christian lifestyle denotes a praxis methodos wherein one has to make decisions between arete [virtues that describes a good life] and kakia [badness]. In order to comply with the criteria for a 'good life', one has to walk the way of God - a way that is determined by the saving activity of God (Ps 67:3) and explained in the commandments (Gn 18:19).

Life in theology is in essence theonomous. It means that Yahweh is the author of life (Jr 17:13; Ps 36:9). 'Yahweh formed man from the dust of the ground and breathed divine breath into the lifeless body so that he became a living being (nēpeš hayyâ)' (Link 1976:478). The implication is that the whole physical, emotional and intellectual life of a human being stems from God.

The Greek notion of life, which is aloof and contemplative (theōrettikos), is foreign and strange to Hebrew thinking. The ideal of Israelites was a life of active involvement, a life expressed by hunger and thirst, desires and lusts:

To the Israelites, as to the oriental in general, the sheer vitality, concreteness and diversity of life were a course of the utmost delight (1 Ki. 3:11; Prov. 3:16; Job2:4); life synonymous with health, well-being and success (Mal. 2:5; Prov. 2:19; Ps. 56:13; Eccl. 9:9). (Link 1976:478)

One can summarise the structures of life that denotes a practical theology of lifestyles in Christian wisdom thinking as:

- Life is valuable because of Christ as the origin and Author of new life - the eschatological dimension of life.

- Life is purposeful. One lives 'for ...'; 'living for ...' and 'living with ...' belong to the very structure of life (Link 1976:481).

- Life is to live within; within fellowship with and communion with others.

- Life is to live with vocation; is about outreach to the needs and predicaments of suffering human beings; and it is about sharing and hospitality.
- Life is to live within the boundaries of time, framed by destruction and deathand thus the reason why, over against present life, there stands the life to come (Mk 10:30); eternal life (zōe aiōnes; Mt 19:16). One should therefore live a virtuous and godly life (praxis pietatis).

- Life is to live from a source, the word of God (Mt 4:4). 'True life depends on the word of God' (Link 1976:480).

- Life is to be exemplified and displayed as habitus - the attitude of Christ (Phlm 2:5). It should be displayed in bodily life, because there is no a dualism between the spiritual and earthly realm; there is no devaluation of earthly life and should thus be sanctified.

- Life is to live within the tension between present and future, between indicative and imperative (Gl 5:25). The new life, as determined by the resurrection of Christ, '... exists already but has not yet been fully manifested (Col 3:3)' (Link 1976:481).

- Life is a gift of God. This gift is received and internalised by means of faith and thus the reason why faith should be evolved in life care. He who believes in the Son has life (1 Jn 5:12).

It was the argument of Henri Bergson (1946:190) that sympathy connects human beings to life - it penetrates the essence of being. 'We call intuition here the sympathy by which one is transported into the interior of an object in order to coincide with what there is unique and consequently inexpressible in it'. To study 'the functioning of life' one has to probe by means of symbols (visual symbols) the habitual function of an object or entity. Sympathising is about the spiritual act of intuitive engagement with the habitual functioning of an object by means of symbols.

Within the parameters of Christian spirituality, my argument will be that compassion gives one access to the very essence of being in a praxis of pastoral caregiving. A practical theology of life should therefore revisit the roots of the Christian understanding of hesed [mercy] and oiktirmos [compassion] of God. It should found a caregiving praxis in a theology of compassion (Louw 2016).

\section{Towards a praxis of divine vivendi: from a 'definition of divine immutability' to an 'infinition of divine being'}

Applied to the realm of theory formation in theology, the implication of the complexification theory and the principle of 'elan vital' will be to move from a fixed dogmatic approach to a more flexible dynamics of hermeneutics within different cultural contexts, that is, the dynamics of 'precensing' - a position of 'not knowing' 35 and being open for the mystery and surprise of God's intervention from the 'eschaton' into the vulnerability of the existential here and now of daily events. As Bergson (1944:271) concludes: 'God thus defined, 35. Kempen (2015:220-221) advocates for a view on the future that deals with unpredictability and the factor of not knowing. 
has nothing of the already made; He is unceasing life, action, freedom.'

The point is that the concept God in the Old Testament refers to the infinitive of a verb. In the case of the noun Jahve, derived from the verb $h j h$ (Hebrew) indicates a vivid promise that Jahvē will always be there where humans are. God is an Exodus-God not a cathedral-God. The presence of God in this regard attains the mode of an infinitive, namely an ongoing divine endeavour - an indication of a sustainable faithfulness under all conditions.

Old Testament studies assert that the Jewish and Christian God is more verb- than noun-like. 'Several biblical scholars translate God's answer to Moses' request for God's name in Exodus 3:14, YHWH, as 'I am who I am becoming', rather than the etymology of YHWH, 'I am who I am.' (MillerMcLemore 2012:8) The point is, in either case, $\mathrm{YHWH}$ is a 'verbal form' ${ }^{36}$ and indicates the sustainable presence of an on-going intervention and promise of God's faithful and covenantal being-with, rather than a metaphysical entity interpreted in terms of immutable categories.

The name Jahve does not describe a fixed theological principle or definition of a substance or static noun, or imperialistic threat power (pantokrator) ${ }^{37}$ it rather points to what one can call infinisciences of divine engagements (on-going modes of divine interventions through and by the indwelling Spirit of God within the functions of the church as expressions of God's presence in this world). Infiniscience is, in essence, a pneumatological concept.

Infiniscience also expresses the promissio-character of the hesed of God to Moses in the Exodus 3:1-22 narrative.

Compassion is linked to the Hebrew meaning of the name of God as expressed in the continuous tense of the verb to be: haja. The name of God has thus future, hopeful implications for the quality of life emanating from the vivid presence of the Lord (YHWH): 'I am that I am' or 'I will be who I will be'. In this name, his El Shaddai [all-empowering presence], will be displayed as a co-suffering source of encouragement, resilience and hope. Through his unfolding actions of comfort and care (the praxis of God), faithful people will discover that even in the complexity of unpredicted events, God does not necessarily explain what is happening, but that he displays his mercy (hesed) despite the paradoxes that often leads to the outcry of human beings in anguish and despair.

36.In English, "gerunds are words that end with -ing and look like verbs but function as nouns. That is, they are nouns (words that name persons, places, ideas, etc.) that contain action; they are verbs used as nouns' (Miller-McLemore 2012:8).

37. Hall (1993:133) asserts that one of the most repressing God-images of Christian theism and cultural Christian imperialism was 'The Father Almighty' - an image which was misused in the North American continent to insulate people from the reality of their situation. Such a theology, he argues, constitutes part of the repressive mechanisms of a class that can still camouflage the truth, because it is well padded economically and physically, and that this theology, accordingly, is partly responsible for the oppression of others who suffer from First World luxury, aggressiveness and self-deceit (Hall 1993:133). Hall (1993:134) calls such theology that maintains the image of deity, based on a power principle that can only comfort the comfortable, 'a flagrantly disobedient theology'. Indeed, God comforts the afflicted, but also afflicts the comfortable.
In order to conclude one can say that the name of God refers more to a verb in the continuous tense than a fixed substance in the past tense; thus, the following theological paradigm shift: from the omniscience of God to the infiniscience of God. The infiniscience of God indicates that his power is less about a causative threat-power and more about a compassionate comfort-empowerment; infiniscience displays sustainable and on-going faithfulness and grace. God is the living God within the covenantal inifiniscience - the God of Abraham, Isaac and Jacob. The fact is that the esed and oiktirmos of God have implications for both the naming of God in the praxis of caregiving and a Christian anthropology. esed and oiktirmos define God as a compassionate Companion and intimate Partner for spiritual wholeness in life. They define human beings as agents and beacons of hope and wounded healers of life despite the sig-sag patterns of suffering.

Due to ta splanchna [the bowel categories of merciful compassion], God should be introduced to suffering human beings as a compassionate Companion. The implication is that 'human soul' (nêfēsh), should be compassionate:

$\ldots$ and it is to understand that undergoing the dispossession of self, entailed by compassion, is to align our own 'being' with God's 'being', and thus, performatively, to participate in the ecstatic ground of the Holy Trinity itself. (Davies 2001:252)

Within an 'open system' and the painful awareness of complexity and paradox, the focus is not on 'omniscience' and 'omnipotence' (the Ceasar notion of an all-powerful imperium - omni-category) and the eventual spin off of fear. The focus is rather on sustainable processes of hoping and the link with a to-be-God, an infiniscient God. Infiniscience points to the ongoing intervention of Jahve and the steadfast faithful presence of a covenantal God in all spheres of life (Louw 2016).

\section{Conclusion}

Fides quaerens vivendi points to the following praxis principle: the whole of human life stands under the will of God and could thus be called a way (Ps 119:105). Such a lifestyle is guided and informed by wisdom. 'Wisdom maintains that wise conduct leads to a successful life, but that foolishness leads to death (Ps1)' (Ebel 1978b:938). Wisdom is needed due to the complexity of life; life oscillates between salvation or destruction. For example, the emphasis in the Sermon on the Mount (Mt 7:131) indicates that the spiritual practice of a Christian way of life displays a picture of two double ways: destructive (hatred and resistance) or constructive (healing and peace).

Fides quaerens vivendi is closely connected to Christology. In John's Gospel, hodos [way] is applied to the person of Christ: 'I am the way' (Jn. 14:6). In Acts 24:14, Christians and belonging to the church were called 'the people of the way'. Association and identification with the message of the resurrection of the crucified one (Acts 22:4), brought about suffering and persecution:

We shall, therefore, be obliged to understand 'way' in its absolute use in Acts as a designation for Christians and their proclamation 
of Jesus Christ, which includes the fact that this proclamation also comprises a particular walk of life or way. (Ebel 1978b:942)

It implies what Paul calls in 1 Corinthians 12:31b 'the more excellent way' of life (agapēe).

Life in practical theological reflection is in essence determined by an eschatological principle; it is shaped and determined by a theology of the resurrection (theologia resurrectionis). It also points to pneumatology, a kind of praxis informed by habitional theology, namely how to demonstrate and exhibit the gifts of the Spirit (charisma) in everyday living. The charisma and pneumatology of fides quaerens vivendi point to what Sperry (2007:70) describes as a taxonomy of spiritual practices determined by moral character ${ }^{38}$ and the ethos of sacrificial ethics (Gerhardson 1981). Fides quaerens vivendi is an inclusive category; it points to a practical theology of hospitality, generosity and service - the so-called praxis pietatis.

\section{Acknowledgements Competing interests}

The author declares that he has no financial or personal relationships which may have inappropriately influenced him in writing this article.

\section{References}

Antonovsky, A., 1979, Health, stress and coping: New perspectives on mental and physical well-being, Jossey-Bass, San Francisco.

Baker, L.R., 2007, The metaphysics of everyday life: An essay in practical realism, Cambridge University Press, Cambridge. https://doi.org/10.1017/CBO9780511487545

Barton, D., 1977, Dying and death, Williams \& Wilkins, Baltimore.

Berdjajew, N., 1965, 'Nicolai Berdjajew', in Te Deum Heute, 365 Texte zur Krisis des Christentums gesammelt und herausgegeben vor Kurt Ihlenfeld, pp. 70-81, EckartVerlag, Witten/Berlin.

Berglund, A-I., 1967, 'African Concepts of Health, Sickness and Death', report of the missiological Institute Umpumulo Consultation of the Healing Ministry of the Church, Lutheran Theological College, Mapumolo.

Bergson, E., 2015, Catholicity challenging ethnicity: An ecclesiological study of churches in post-apartheid South Africa, Uppsala University Press, Uppsala.

Bergson, H., 1921, Mind-energy: Lectures \& essays, Macmillan \& Co, London.

Bergson, H., 1944, Creative evolution, The Modern Library, New York.

Bergson, H., 1946, The creative mind, Philosophical Library, New York.

Berinyuu, A.A., 1988, Pastoral care to the sick in Africa: An approach to transcultural pastoral theology, Peter Lang, Frankfurt.

Browning, D.S., 1983a, Practical theology, San Francisco, Harper \& Row.

Browning, D.S., 1983b, 'Pastoral theology in a pluralistic age', in D.S. Browning (ed.), Practical theology, pp. 187-202, Harper \& Row, San Francisco.

Browning, D.S., 1991, A fundamental practical theology Fortress Press, Minneapolis.

Burkhart, J.E., 1983, 'Schleiermacher's vision for theology', in D.S. Browning (ed.) Practical theology, pp. 42-60, Harper \& Row, San Francisco.

Casdorff, Von S-A., 2016, 'Gefährdete Demokratie: Rational gegen radikal', Der Tagesspiegel, 5 Februar, p. 1.

Castels, S. \& Miller, M.J., 2009, The age of migration: International population movements in the modern world, Castillo Guerra, New York, London.

Cilliers, J., 2012, Dancing with Deity: Re-imagining the beauty of worship, Bible Media, Wellington.

Coole, D. \& Frost, S., 2010, 'Introducing the new materialisms', in D. Coole \& S. Frost (eds.), New materialisms: Ontology, agency and politics, pp. 1-46, Duke University Press, Durham, London. https://doi.org/10.1215/9780822392996-001

Davies, O., 2001, A theology of compassion: Metaphysics of difference and the renewal of tradition, William B. Eerdmans Publishing Company, Grand Rapids, Cambridge.

38. Moral character, according to Sperry (2002:70), is related to habit and virtue Habits are regular patterns of activity; virtues are perfected, rightly ordered habits, while vices are perfected, wrongly ordered habits.
Deetz, S.A., 1992, Democracy in an age of corporate colonization Developments in communication and the politics of everyday life, State University of New York Press, Albany.

De Gruchy, J.W., 2001, Christianity, art and transformation: Theological aesthetics in the struggle for justice, Cambridge University Press, Cambridge.

De Lubac, H., 1965, 'Nicolai Berdjajew', in Te Deum Heute, 365 Texte zur Krisis des Christentums gesammelt und herausgegeben vor Kurt Ihlenfeld, pp. 78-79, EckartVerlag, Witten/Berlin.

Dillen, A. \& Gärtner, S., 2015, Praktische theologie: Verkenningen aan de grens, Lannoo Campus, Leuven.

Driesch, H., 1925, The crisis in psychology, Princeton University Press, Princeton.

Ebel, G., 1978a, 'Anastrephō', in C. Brown (ed.), The New International Dictionary of New Testament theology, vol. 3, pp. 933-935, Exeter, The Paternoster Press.

Ebel, G., 1978b, 'Hodos', in C. Brown (ed.), The New International Dictionary of New Testament theology, vol. 3, pp. 935-943, The Paternoster Press, Exeter.

Ebel, G., 1978c, 'Peripateō', in C. Brown (ed.), The New Internationa Dictionary of New Testament Theology, vol. 3, pp. 943-945, The Paternoster Press, Exeter.

Farley, E., 1983, 'Theology and practice outside the clerical paradigm', in D. Browning (ed.), Practical Theology, pp. 21-41, Harper \& Row, San Francisco.

Ferreira, N., 2009, 'Wolf en Rooikappie', By (Burger), 9 Mei, bl. 4.

Eynikel, E., 1991, 'De wijsheidsliteratuur van het oude nabije Oosten', in E. Eynikel (ed.), Wie wijsheid zoekt, pp. 1-45, Acco, Leuven.

Ganzevoort, R.R., 2002, 'WYSIWYG, social construction in practical theological epistemology', Journal of Empirical Theology 15(2), 34-42.

Gerhardson, B., 1981, The ethos of the Bible, Fortress Press, Philadelphia. https://doi. org/10.1515/9783110221121

Grethlein, C., 2012, Praktische Theologie. De Gruyter, Berlin, Boston.

Grunwald, M., 2014, 'The second age of reason: Information overload will improve our lives,' Time, 8 September/15 September pp. 33-35.

Hall, D., 1993, Professing the faith, Fortress Press, Minneapolis.

Han, B-C., 2013, Im Schwarm: Ansichten des Digitalen, Matthes \& Seitz, Berlin.

Heidegger, M., 1963, Sein und Zeit, Max Niemeyer Verlag, Tübingen.

Heitink, G., 1993, Praktische theologie: Geschiedenis, theorie, handelingsvelden, Kok, Kampen.

Heyns, L.M. \& Pieterse, H.J.C., 1990, Eerste tree in die praktiese teologie, Gnosis, Pretoria. Josuttis, M., 1980, Praxis des Evangeliums zwischen Politik und Religion, Chr. Kaiser, München.

Kahiga, J.K., 2005, 'Epistemology and praxis in African cultural context', African Ecclesial Review [AFER], 47(3), 184-198.

Karaflogka, A., 2002, 'Religion on - religion in cyberspace', in G. Davie, P. Heelas \& L. Woodhead (eds.), Predicting religion: Christian, secular and alternative futures, pp.191-202, Aldershot, Ashgate.

Kaunda, K., 1967, A humanist in Africa: Letters to Colin Morris, Longman, London.

Keane, J., 2003, Global civil society? Cambridge University Press, Cambridge. https:// doi.org/10.1017/СBO9780511615023

Kempen, M., 2015, Coaching als abduktiver Prozess vor dem bleibenden Geheimnis: Die Theorie von $U$ aus pastoralpsychologischer Perspektive, Theologische Hochschule Sankt Georgen, Frankfurt am Main.

Kessler, T., 2014, Migration als Ort der Theologie, Verlag Friedrich Pustet, Regensburg.

Korsch, D., 2011, 'Life science - gelebte Religion - Theologie als Lebenswissenschaft', in T. Klie, M. Kumlehn, R. Kunz \& T. Schlag (Hrsg.), Lebenswissenchaft Praktische Theologie?! Praktische Theologie im Wissenschaftsdiskurs, Band 9, pp. 341-344, De Gruyter Berlin, New York.

Kumlehn, M., 2011, 'Einleitung: Praktische Theologie als Lebenswissenschaft?!' in T. Klie, M. Kumlehn, R. Kunz \& T. Schlag (Hrsg.), Lebenswissenchaft Praktische Theologie?! Praktische Theologie im Wissenschaftsdiskurs, Band 9, pp. 1-8, De Gruyter, Berlin, New York.

Lauster, J., 2007, 'Leben: Genetischer Code/Lebensphilosophie/inneres Leben/ewiges Leben', in W. Gräb \& B. Weyel (Hrsg.), Handbuch Praktische Theologie, pp. 137148, Gütersloher Verlagshaus, Gütersloh.

Leiner, M. \& Palme, M., 2014, 'Introduction to the present volume', in M. Leiner, M Palme \& P. Stöckner (eds.), Societies in transformation. Sub-Saharan Africa between conflict and reconciliation, pp. 1-12, Vandenhoeck \&Ruprecht, Göttingen. https://doi.org/10.13109/9783666560187.9

Life science, 2016, viewed 30 June 2016, from https://en.wikipedia.org/wiki/List_of_ life_sciences

Link, H-G., 1976, 'Life (bios)', in C. Brown (ed.), The New International Dictionary of New Testament theology, vol. 2, pp. 474-483, The Paternoster Press, Exeter.

Louw, D.J., 2008, Cura Vitae: IIIness and the healing of life, Lux Verbi, Wellington.

Louw, D.J., 2016, Wholeness in hope care: On nurturing the beauty of the human soul in spiritual healing, LIT Verlag, Berlin.

Mandela, N., 2005, In the words of Nelson Mandela, Penguin Books, London.

Maree, J.G., 2013, 'Life design: An approach to managing diversity in South Africa', in M.P. Wissing (ed.), Well-Being research in South Africa: Cross-cultural
advancements in positive psychology, vol. 4, pp. 53-65, Springer New York, advancements in positive psychology, vol. 4, pp. 53-65.
London. https://doi.org/10.1007/978-94-007-6368-5_4 
McLuhan, H.B., 2015, viewed 20 October 2015, from https://en.wikipedia.org/wiki/ Marshall_McLuhan\#cite_note-45

Morin, E., 1992, Method: Towards a study of mankind: The nature of nature, vol. 1, Peter Lang, New York.

Morin, E., 2008, On complexity, Hampton Press, Inc., Cresskill.

Miller-McLemore, B.J., 2012, 'Introduction: The contributions of practical theology', in B.J. Miller-McLemore (ed.), The Wiley-Blackwell companion to practical theology pp. 1-20, A. Wiley \& Sons Ltd., Malden, Oxford, Chichester.

Murphy, R.E., 1990, The tree of life: An exploration of Biblical wisdom literature, Doubleday, New York.

Mtetwa, S., 1996, 'African spirituality in the context of modernity', Bulletin for Contextual Theology in Southern Africa and Africa 3(2), 21-25.

Nell, I., 2017, We know to whom we belong? The drama of ministry practice in a postcolonial African context, Faculty of Theology, Sun Media, Stellenbosch.

Niebuhr, H.R.,1952, Christ and culture, Faber \& Faber, London.

Nilson, F., 2007, 'Towards a dialectic complexity framework: Philosophical reflections', in K.A. Richardson \& P. Cilliers (eds.), Explorations in complexity thinking: PreProceedings of the 3rd International Workshop on complexity and philosophy, pp. 236-249, ISCE Publishing, Mansfield.

Osmer, R.R., 2008, Practical theology. An introduction, Eerdmans, Grand Rapids.

Plato, 1946, The republic of Plato, transl. with introduction and notes F.M Cornford, Clarendon Press, Oxford.

Plato, 2015, The failure of democracy, viewed 16 May 2015, from http://faculty. frostburg.edu/phil/forum/PlatoRep.htm

Polak, R., 2014, 'Migration als Ort der Theologie', in T. Kessler (ed.), Migration als Or der Theologie, pp. 1-20, Verlag Friedrich Pustet, Regensburg.

Reader, J., 2008, Reconstructing practical theology: The impact of globalization, Templeton Press, Aldershot, Ashgate.

Reuters, 2015, 'Paris killings an attack on the civilised world, says Obama', Cape Argus, 16 November, p. 11.

Rothman, S., 2013, 'From happiness to flourishing at work: A Southern African perspective', in M.P. Wissing (ed.), Well-being research in South Africa: Cross-cultural advancements in positive psychology, vol. 4, pp. 123-152, Springer, Dordrecht, Heidelberg, New York, London. https://doi.org/10.1007/978-94-007-6368-5_7

Sartre, J-P., 1943, L'Être et le Néante, Gallimard, Paris.

Seligman, J., 1992, The idea of civil society, Free Press, New York.

Skhakhane, J., 1995, 'African Spirituality', in M. Makobane et al. (eds.), The church and African culture, pp. 104-110, Lumko, Germiston.
Smith, A., \& Riedel-Pfaefflin, U., 2004, Siblings by choice, Chalice Press, St Louis.

Snedeker, G., 1984, 'Sartre, Althusser and the ontology of everyday life', Dialectical Anthropology 8(4), 277-291. https://doi.org/10.1007/BF00246005

Sperry, L., 2002, Transforming self and community: Revisioning pastoral counselling and spiritual direction, The Liturgical Press, Collegeville.

Stace, W.T., 1960, A critical history of Greek philosophy, MacMillan, London.

Strümpfer, D.W.J., 2013, 'Towards fortigenesis and fortology: An informed essay', in M.P. Wissing (ed.), Well-being research in South Africa: Cross-cultural advancements in positive psychology, vol. 4, pp. 7-38, Springer, Dordrecht, Heidelberg, New York, London. https://doi.org/10.1007/978-94-007-63685_2

Silverstone, R., 1994, Television and everyday life, Routledge, Abingdon. https://doi. org/10.4324/9780203358948

Tacke, H., 1975, Glaubenshilfe als Lebenshilfe, Neukirchener, Neukirchen-Vluyn.

Taleb, N.N., 2010, The black swan: The impact of the highly improbable, Penguin Books, London.

Taleb, N.N., 2012, Antifragile: Things that gain from disorder, Penguin Books, London.

Tutu, D., 2004, 'Nelson Mandela annual lecture', viewed 20 September 2014, from http://nelsonmendela.org/uploads/files/NMF_Lecture_Book_small.pd

Twesigye, E.K., 1996, African religion, philosophy, and Christianity in logos-Christ: Common ground revisited, Peter Lang, New York.

Van Binsbergen, W., 2003, Intercultural encounters: African and anthropological lessons towards a philosophy of interculturality, LIT Verlag, Münster.

Van der Ven, J.A., 1988, 'Practical theology: From applied to empirical theology', Journal of Empirical Theology 1(1), 7-77. https://doi.org/10.1163/157092 $588 \times 00023$

Van der Ven, J.A., 1990, Entwurf einer emprischen Theologie, Kok, Kampen.

Vick, K., 2015, 'The great migration', Time, 19 October, pp. 26-34.

Villa-Vicencio, C., 1994, 'Theology and culture in South Africa: Beyond multiculturalism', Theology Today, 51(2), 115-126. https://doi.org/10.1177/ 004057369405100110

Walt, V., 2015, 'World: An attack foretold', Time, 19 January, pp. 8-9.

Wissing, M.P., 2013, 'Introduction', in M.P. Wissing (ed.), Well-being research in South Africa: Cross-cultural advancements in positive psychology, vol. 4, pp. 1-6, Springer, Dordrecht, Heidelberg, New York, London. https://doi.org/10.1007/97894-007-6368-5_1 